\title{
DETEKSI CACAT RODA GIGI PADA SISTEM TRANSMISI FAN INDUSTRI MENGGUNAKAN SUPPORT VECTOR MACHINE
}

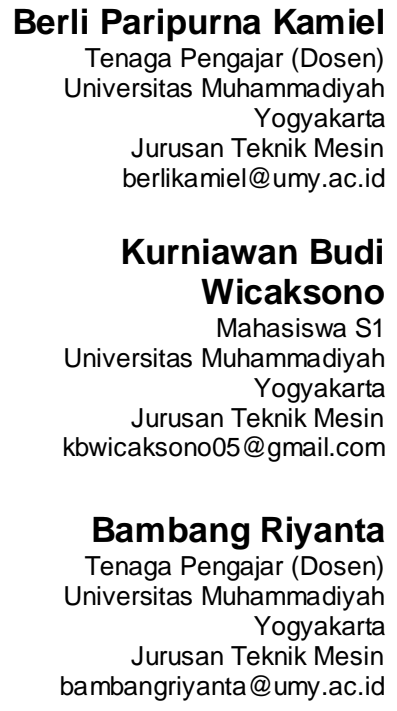

A fan is a mechanical device that produces airflow in a particular area. To achieve sufficient torque and speed, an industrial fan often uses a gear transmission. During its operation, the gears may experience damage. The vibration spectrum is a common method to detect a faulty gear. However, the spectrum often produces a graph that is hard to understand. Moreover, the spectrum sometimes fails to show a clear and high amplitude for small gear faults. The study aims to detect faulty gear based on a classification approach using the Support Vector Machine (SVM) algorithm. It is one of the most robust and accurate algorithms among the other classification algorithms especially for cases with a large number of features. The SVM needs statistical parameters as predictors but the decision to choose the parameters seems arbitrary. This research proposes a simple method to select the parameters using a combination of visual inspection and relieffeature algorithm. Twelve statistical parameters are introduced and evaluated for potential input for SVM. The statistical parameters are extracted from the time domain of the vibration signal. The experiment is carried out on an industrial fan test rig and introduces 3 carbon steel spur gear conditions i.e. normal, fault 1, fault 2, and records vibration signal using an accelerometer located near the gear transmission system. The SVM classifier is built using the RBF kernel function and the classification is carried out by one vs one and one vs all methods. The result shows that classification accuracy for both methods achieves $100 \%$.

Keywords: Fan, Gear Fault, Radial Basic Function, Support Vector Machine, Statistical Parameter

\section{PENDAHULUAN}

Fan adalah alat mekanik yang berfungsi mensirkulasikan aliran udara yang terdiri dari beberapa komponen yaitu sudu, bantalan, poros dan sistem transmisi roda gigi. Berbeda dengan kompresor yang menghasilkan udara bertekanan dengan laju aliran rendah, fan menghasilkan laju aliran tinggi dan tekanan rendah [1]. Rangkaian sistem transmisi merupakan komponen kritis pada sebuah fan. Kegagalan sistem transmisi dapat menyebabkan turunnya performa pada sebuah fan dan berpotensi mengganggu suatu proses secara keseluruhan [2]. Deteksi kerusakan atau cacat pada transmisi roda gigi penting dilakukan untuk menghindari perbaikan tidak terjadwal yang merugikan.

Sinyal getaran adalah parameter yang banyak digunakan dalam mendeteksi kerusakan berbagai komponen mesin. Telah dipahami secara luas bahwa parameter getaran seperti frekwensi dan amplitudo adalah khas untuk setiap komponen mesin dan parameter tersebut berubah jika sebuah komponen mengalami kerusakan [3]. Domain waktu dan spektrum adalah dua teknik utama berbasis getaran yang digunakan dalam mendeteksi kerusakan. Domain waktu mendeskripsikan kronologi getaran sedangkan spektrum menunjukkan komponen frekwensi yang terjadi pada getaran mesin. Namun demikian kedua teknik tersebut tidak selalu mudah digunakan oleh operator di lapangan. Dibutuhkan seorang operator yang terlatih untuk menterjemahkan domain waktu dan spektrum sebelum mengambil kesimpulan terjadi kerusakan pada sebuah komponen mesin.

Penerapan machine learning untuk tugas-tugas klasifikasi semakin mendapat perhatian di bidangbidang keteknikan dalam 10 tahun terakhir. Algoritma machine learning mampu mengenali dan mengklasifikasi kelompok-kelompok data dengan akurasi yang tinggi, rata-rata di atas $85 \%$. Penelitian yang 
dilakukan oleh Sahoo dkk [4] menunjukkan akurasi klasifikasi roda gigi cacat mencapai 99\%. Algoritma machine learning yang digunakan adalah random forest dengan input 6 parameter statistik hasil ekstraksi sinyal akuistik. Algoritma decision tree berbasis sinyal getaran digunakan oleh Vernekar dkk [5] untuk mendiagnosis kerusakan roda gigi dan bantalan pada kotak transmisi kendaraan penumpang; akurasi yang diperoleh adalah $85.5 \%$. Beberapa penelitian lainnya yang menggunakan decision tree untuk mendeteksi kerusakan pada mesin-mesin rotari dilaporkan oleh beberapa peneliti [6-8].

Diagnosis kerusakan pada roda gigi menggunakan algoritma SVM oleh Ma dkk. [9] menghasilkan akurasi lebih dari $90 \%$. Penelitian berbasis sinyal getaran tersebut menggunakan tiga mode kerusakan roda gigi dengan dua variasi kecepatan. Hasil penelitian menunjukkan SVM efektif dalam mengklasifikasi data dengan jumlah sampel kecil. Cheng dkk., [10] menggunakan autoregresive (AR) dari intrinsic mode functions (IMFs) sinyal getaran sebagai parameter input SVM untuk mengklasifikasi kondisi roda gigi. Kombinasi AR, IMFs dan SVM menunjukkan akurasi maksimal sebesar 100\% walaupun jumlah data yang digunakan sedikit. Tang dkk., [11] mengusulkan metode baru yanng mengkombinasikan teknik mereduksi dimensi menggunakan manifold learning dan modifikasi SVM yaitu Shannon wavelet support vector machine (SWSVM) untuk mendeteksi kerusakan transmisi pada turbin angin. Kondisi operasi turbin angin yang non-stasioner menghasilkan ekstraksi parameter berdimensi tinggi yang perlu direduksi sebelum menjadi input SWSVM. Akurasi yang didapatkan dengan metode kombinasi ini adalah 92\%. Penelitian oleh Chao dkk., [12] menyelidiki tiga kelompok kondisi roda gigi heliks yang berbeda untuk klasifikasi pengenalan pola berbasis siyal getaran. Kelompok 1 adalah kondisi normal (tidak cacat), sedangan kelompok 2 dan 3 memiliki bagian cacat yang berbeda. Terdapat 816 data sampel yang diekstrasi dan dibagi menjadi dua bagian. Sejumlah 612 data sampel ditentukan sebagai data pelatihan dan sisinya sebagai data uji. SVM menghasilkan efek diagnostis yang stabil yaitu pada tingkat akurasi $97 \%$ meskipun roda gigi berada pada beban dan kecepatan yang bervariasi.

Parameter statistik umum digunakan sebagai input algoritma machine learning karena memberikan kamampuan memisahkan kelas pada berbagai mesin rotari dengan memuaskan. Berbagai penyelidikan telah dilakukan seperti oleh Amarnath dkk., [13] yang menggunakan 9 parameter, Sugumaran dan Ramachandran [14] menggunakan 11 parameter, Sharma dkk., [15] menggunakan 13 parameter. Walaupun parameter statistik terbukti efektif memisahkan kelas namun jenis dan jumlah parameter yang digunakan berbeda pada masingmasing kasus. Tidak terdapat aturan baku dalam memilih jenis dan jumlah parameter statistik pada suatu aplikasi sehingga terdapat celah penelitian yang berpotensi diselidiki lebih lanjut. Penelitian ini berusaha memilih parameter statistik berbasis domain-waktu getaran yang paling relevan sebagai input algoritma machine learning untuk mendeteksi cacat roda gigi pada sistem transmisi sebuah fan. Sinyal getaran yang berasal dari cacat roda gigi cenderung rumit yang diakibatkan interaksi antar komponen di dalam gearbox. SVM mempunyai keunggulan yang disebut kernel trick yang mentransformasikan data dan memisahkan kelas dengan boundary yang bukan garis lurus sehingga sinyal cacat roda gigi dapat dipisahkan dengan sangat baik. Oleh karena itu penelitian ini menggunakan algoritma SVM sebagai classifier.

\section{TINJAUAN PUSTAKA}

\subsection{Support Vector Machine}

Algoritma SVM merupakan metode yang digunakan untuk klasifikasi biner. Pertama kali SVM dikemukakan oleh Vapnik pada tahun 1992 dengan menggabungkan beberapa rangkaian konsep di bidang pengenalan pola. Pada dasarnya, metode ini bekerja dengan menemukan hyperplane terbaik yang memisahkan kelompok data dengan sempurna ke dalam dua kelas [16].

Gambar 1(a) menunjukkan pola dari dua kelas (simbol kotak merah dan simbol lingkaran biru). Algoritma SVM selanjutnya berusaha menemukan hyperplane terbaik dengan memunculkan beberapa discrimination boundaries (alternatif garis pisah). Penentukan hyperplane terbaik dilakukan dengan mencari titik maksimal dan mengukur margin nya. Gambar 1(b) memperlihatkan hyperplane terbaik yang terletak ditengah antara kedua kelas, dan pola yang berada di dekat hyperplane merupakan support vector.

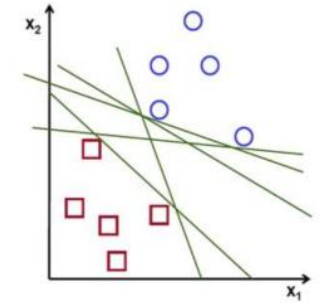

(a)

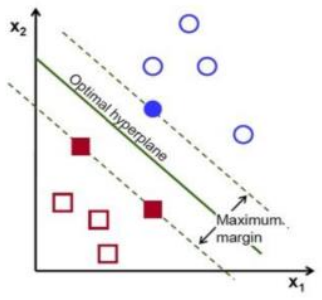

(b)

Gambar 1. Support Vector Machine [17] 
Pola dari kedua kelas tersebut diasumsikan telah terpisah sempurna oleh hyperplane dalam suatu dimensi yang didefinisikan dengan persamaan (1) sampai (8) [16],

$$
\vec{w}+\vec{x}=0
$$

jika $\overrightarrow{x_{l}}$ pada kelas -1 , maka

$$
\vec{w} \cdot \vec{x}+b \leq-1
$$

Sedangkan nilai $\overrightarrow{x_{l}}$ pada kelas +1 ,

$$
\vec{w} \cdot \vec{x}+b \geq+1
$$

Quadratic Programming (QP) problem merupakan usaha dalam memaksimalkan nilai jarak antara hyperplane dan titik terdekatnya dengan mencari titik minimalnya

$$
\begin{aligned}
& \min \vec{w} \tau(w)=\frac{1}{2}\|w\|^{2} \\
& y_{i}\left(\vec{x}_{i} \cdot w+b\right)-1 \geq 0, \forall_{i}
\end{aligned}
$$

Permasalahan pada persamaan (4) dan (5) dapat diselesaikan dengan teknik Lagrange Multiplier $\left(\alpha_{i}\right)$, sehingga

$$
L(\vec{w}, b, \alpha)=\frac{1}{2}\|\vec{w}\|^{2}-\sum_{i=1}^{l} a_{i}\left(y_{i}\left(\left(\overrightarrow{x_{l}} \cdot \vec{w}+b\right)-1\right)\right) ;(i=1,2, \ldots, l)
$$

Selanjutnya persamaan (6) dioptimalisasi dengan memaksimalkan problem yang hanya mengandung nilai $\left(a_{i}\right)$

$$
\sum_{i=1}^{l} a_{i}-\frac{1}{2} \sum_{i, j=1}^{l} a_{i} a_{j} y_{i} y_{j} x_{i} x_{j}
$$

Sehingga, didapat persamaan

$$
a_{i} \geq 0(i=1,2, \ldots, l) \sum_{i=1}^{l} a_{i} y_{i}=0
$$

Pengklasifikasian data oleh algoritma SVM melalui dua tahap yaitu proses pelatihan (training) dan pengujian (testing) data. Proses pelatihan adalah proses pembuatan model yang digunakan sebagai acuan dalam melakukan klasifikasi. Pembentukan model ini memetakan hyperplane optimal menggunakan kernel function RBF. Output yang dihasilkan berupa support vector, yang berupa pola dengan jarak terdekat terhadap hyperplane optimal. Proses testing adalah proses pengujian terhadap data training yang telah dibuat untuk menjamin generalisasi suatu model, dilakukan sebagai tahapan evaluasi terhadap model klasifikasi yang dibangun. Hasil dari proses ini adalah menghitung tingkat akurasi yang diberikan dari pengelompokkan data tersebut.

Pada dasarnya SVM merupakan metode klasifikasi yang bersifat biner. Namun dengan melakukan modifikasi algoritma, klasifikasi multi-class (banyak kelas) dapat dilakukan. Prinsip klasifikasi multi-class dilakukan dengan menerapkan metode one vs one dan one vs all. Metode one vs one, dimana model multiclass dibangun berdasarkan jumlah kelas. Sehingga dari ketiga kelas dapat menghasilkan empat hyperplane optimal. Sedangkan metode one vs all dilakukan dengan mencari satu hyperplane optimal dari tiga kelas.

\subsection{Parameter Statistik}

Algoritma SVM membutuhkan parameter statistik sebagai input untuk membentuk model klasifikasi. Penelitian ini mengusulkan dua belas parameter statistik domain waktu yaitu:

1. Root Mean Square (RMS)

RMS adalah parameter statistik berbasis domain waktu yang didefinisikan sebagai akar kuadrat dari ratarata nilai kuadrat sebuah sinyal.

$$
R M S=\sqrt{\frac{1}{n} \sum_{i=1}^{N}\left(x_{i}-\bar{x}\right)^{2}}
$$

2. Standard Deviation

Standart deviation menunjukkan tingkat energi atau daya yang terdapat pada sebuah sinyal.

$$
S D=\sqrt{\frac{\sum_{i=1}^{N}\left(x_{i}-\bar{x}\right)^{2}}{N-1}}
$$




\section{Variance}

Variance adalah parameter statistik yang menunjukkan seberapa jauh kumpulan data tersebar yang dirumuskan sebagai nilai kuadrat dari nilai standar deviasinya

$$
\text { Variance }=\frac{\left(x_{i}-\bar{x}\right)^{2}}{N-1}
$$

\section{Kurtosis}

Kurtosis adalah parameter yang menunjukkan nilai kelancipan dan kedataran relatif sebuah distribusi dibanding distribusi normal sinyal

$$
\text { Kurtosis }=\frac{\sum_{i=1}^{N}\left(x_{i}-\bar{x}\right)^{4}}{(N-1) \sigma^{4}}
$$

5. Minimum Value

Minimum value menggambarkan titik terendah dari data yang dihasilkan dari suatu kelompok data.

6. Crest Factor

Crest factor diartikan sebagai rasio dari nilai tertinggi dari sinyal masukan terhadap nilai RMS. Crest factor merupakan parameter yang menggambarkan ukuran ketajaman dan banyak peak dalam suatu sinyal

$$
C_{f}=\frac{\max (|x(n)|)}{\sigma}
$$

7. Peak Value

Peak value merupakan parameter statistik yang digunakan sebagai penunjuk indeks intensitas energi pada sinyal getaran

$$
\text { Peak }=\max |x(N)|
$$

\section{Entrophy}

Entrophy adalah fungsi distribusi suatu sistem pada kondisi mikro. Atau dapat didefinisikan sebagai besaran atau nilai yang menyatakan keadaan mikroskopis suatu sistem sehingga tidak dapat diketahui secara langsung

$$
S=\sum_{i=1}^{N} p\left(x_{i}\right) \log _{10} p(x i)
$$

9. Mean

Mean adalah nilai yang yang didapat dari nilai rata-rata kelompok tersebut.

$$
\text { Mean }=\frac{1}{K} \sum_{k=1}^{K} x(k)
$$

10. Skewness

Skewness menunjukkan tingkat kesimetrisan distribusi disekitar daerah rata-ratanya

$$
\text { Skewness }=\frac{\sum_{i}^{N}\left(X_{i}-\bar{X}\right)^{3}}{(N-1) \sigma^{3}}
$$

\section{Maximum Value}

Maximum value menggambarkan titik tertinggi dari data yang dihasilkan dari suatu kelompok data.

\section{Median}

Median merupakan parameter statistik yang menunjukkan nilai tengah dari suatu kelompok data.

$$
\bar{x}=\frac{\sum x}{N}
$$

\section{METODE DAN BAHAN}

Sinyal getaran diambil dari sebuah rig uji prototipe fan industri yang ditunjukkan pada Gambar 2. Komponen rig uji dan system akusisi data terdiri dari motor listrik, transmisi roda gigi, akselerometer, perangkat data akuisisi, dan komputer. 


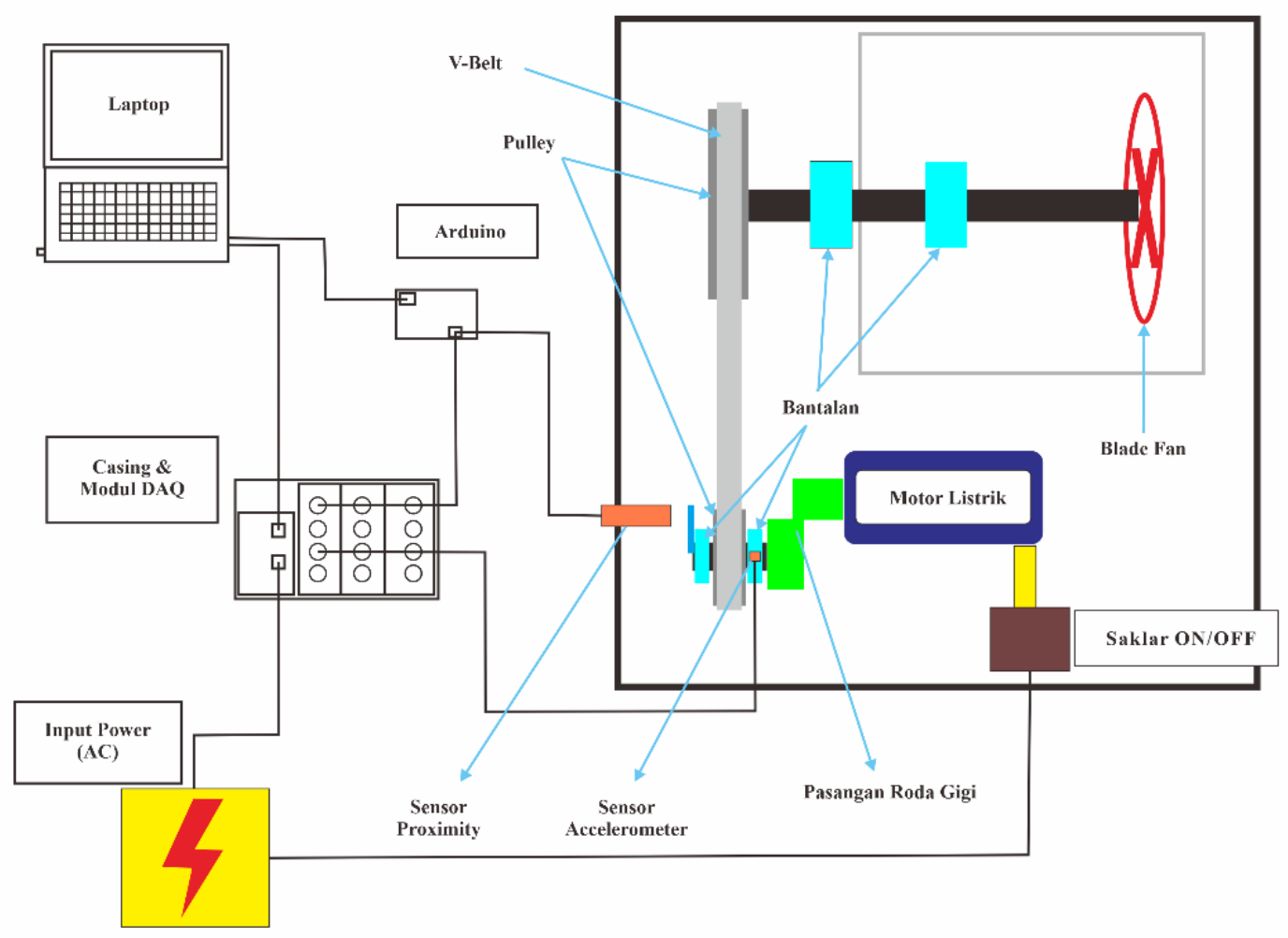

Gambar 2. Skema alat uji

Penelitian ini menggunakan tiga kondisi roda gigi tipe spur gear yaitu kondisi normal (tidak cacat) ditunjukkan pada Gambar 3, kondisi cacat-sebagian pada salah satu giginya ditunjukkan pada Gambar 4, dan kondisi cacat penuh pada salah satu giginya ditunjukkan pada Gambar 5. kondisi cacat pada gigi tersebut dibuat dengan menggunakan teknik wirecut.

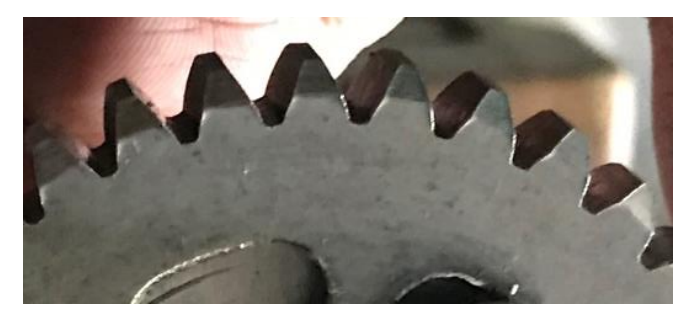

Gambar 3. Kondisi normal (tidak cacat)

Akuisisi sinyal getaran dilakukan menggunakan akselerometer yang diletakkan pada rumah bantalan terdekat dengan roda gigi. Akelerometer yang digunakan adalah dari Bruel \& Kjaer seri 4507 yang dihubungkan ke modul akuisisi data dari National Instrument seri NI 9234. Sampling rate di set pada frekwensi $17066 \mathrm{~Hz}$ sedangkan kecepatan motor dijaga konstan pada 2850 RPM.

Akuisisi sinyal vibrasi dilakukan pada tiga kondisi roda gigi masing-masing sebanyak 500 kali dengan durasi setiap rakaman 10 detik dan jeda 2 detik antar rekamannya sehingga didapat total 1500 set data. Sebanyak 1050 data digunakan sebagai data training dan 450 sebagai data testing. Diagram alir pada Gambar 6 menunjukkan prosedur klasifikasi yang dimulai dengan melakukan ekstraksi 12 parameter statistik dari domain waktu sinyal getaran. Hasil ekstraksi kemudian diseleksi secara visual dan dengan menggunakan algoritma relief feature. Hasil seleksi menggunakan kombinasi dua metode tersebut kemudian dijadikan input SVM. Proses pembuatan classsifier SVM dilakukan dengan melatih 1050 set data training yang kemudian hasilnya diuji dengan 450 set data testing. 

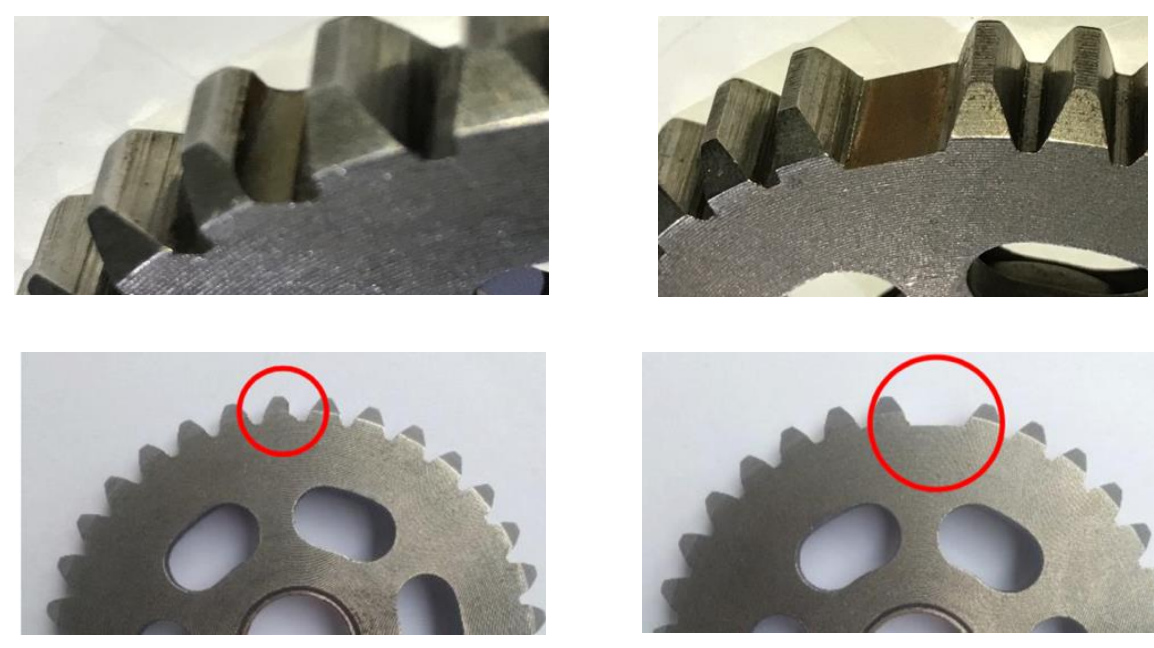

Gambar 4. Kondisi cacat-sebagian

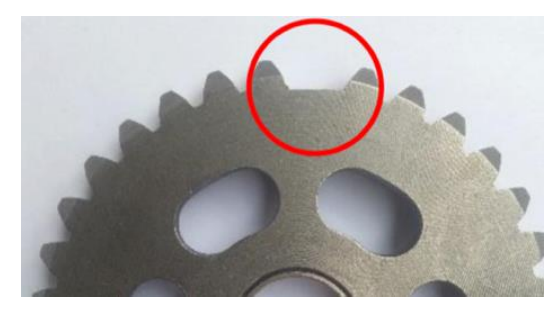

Gambar 5. Kondisi cacat penuh

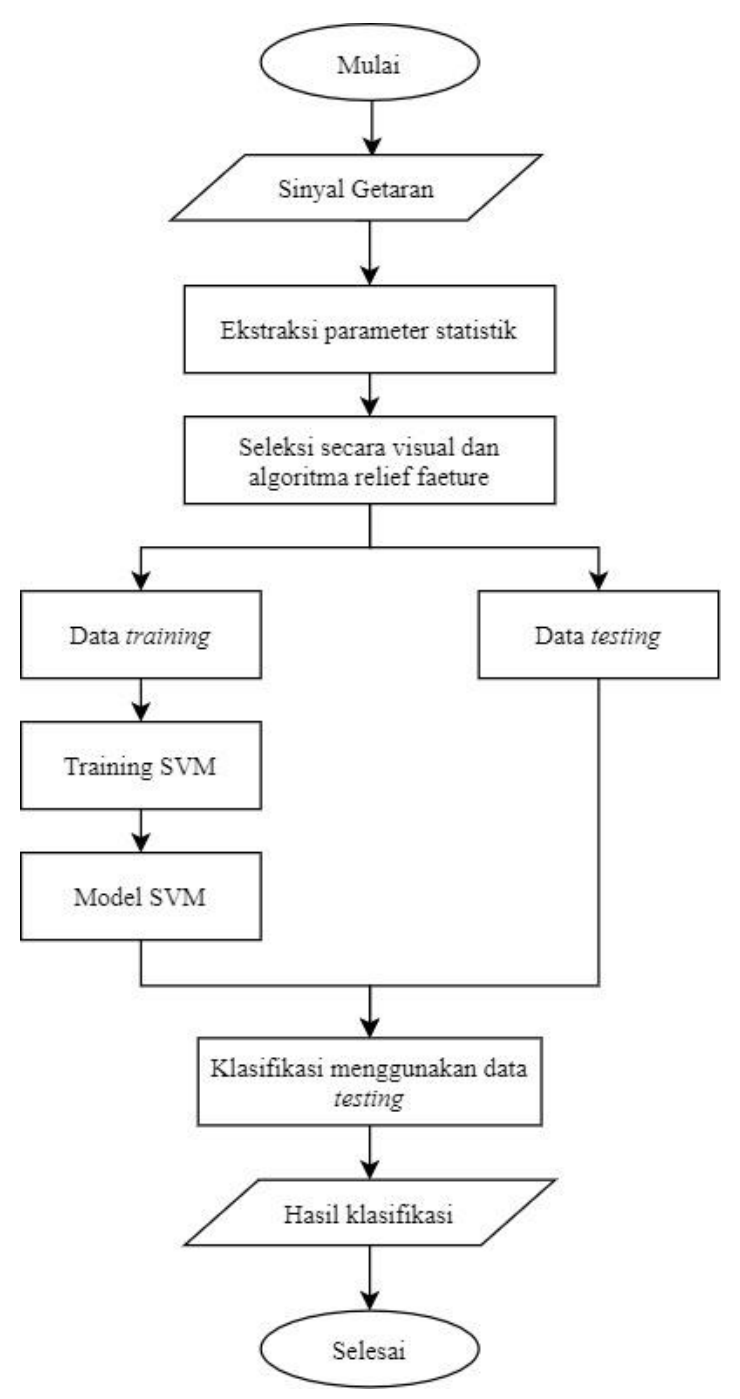

Gambar 6. Diagram alir pengolahan data 


\section{HASIL DAN DISKUSI}

Domain waktu sinyal getaran untuk semua kondisi roda gigi pada Gambar 7 menunjukkan bahwa besar amplitudo getaran sebanding dengan peningkatan level cacat. Hal ini karena amplitudo getaran merupakan representasi energi getaran yang terjadi akibat benturan antar komponen pada sebuah mesin. Benturan ini akan semakin besar dengan semakin besarnya cacat yang terjadi pada roda gigi. Namun amplitudo yang tinggi pada sebuah domain waktu tidak selalu diakibatkan oleh cacat roda gigi karena cacat komponen lain (bantalan, sudu, poros) dari sebuah mesin juga menunjukkan peningkatan amplitudo. Domain waktu memberikan kronologis kejadian komponen-komponen sebuah mesin ketika beroperasi dalam bentuk superposisi amplitudo. Hal ini menyebabkan tidak mudah mengidentifikasi cacat pada sebuah komponen berdasarkan domain waktunya saja.

Klasifikasi kondisi roda gigi berdasarkan parameter statistik domain waktu dimulai dengan memilih parameter yang paling relevan. Dua belas parameter diekstrak dari domain waktu masing-masing kondisi roda gigi seperti ditunjukkan pada Gambar 8 dalam bentuk plot sampel versus nilai parameter. Hasil ekstraksi dalam bentuk plot tersebut menunjukkan bahwa secara visual parameter RMS, Standard, Entropy, Deviasi, Peak Value, Variance dan Maksimum secara visual mempu memisahkan ketiga kondisi roda gigi dengan baik. Hal ini ditunjukkan berturut-turut pada Gambar 8 (a), (b), (c), (d), (e) dan (h) dimana jelas terlihat batas antara kondisi normal, cacat 1 dan cacat 2. Hal sebaliknya ditunjukkan oleh parameter Mean, Kurtosis, Minimum, Median, Crest Factor, dan Skewness pada Gambar 8 (f), (g), (i), (j), (k) dan (l).
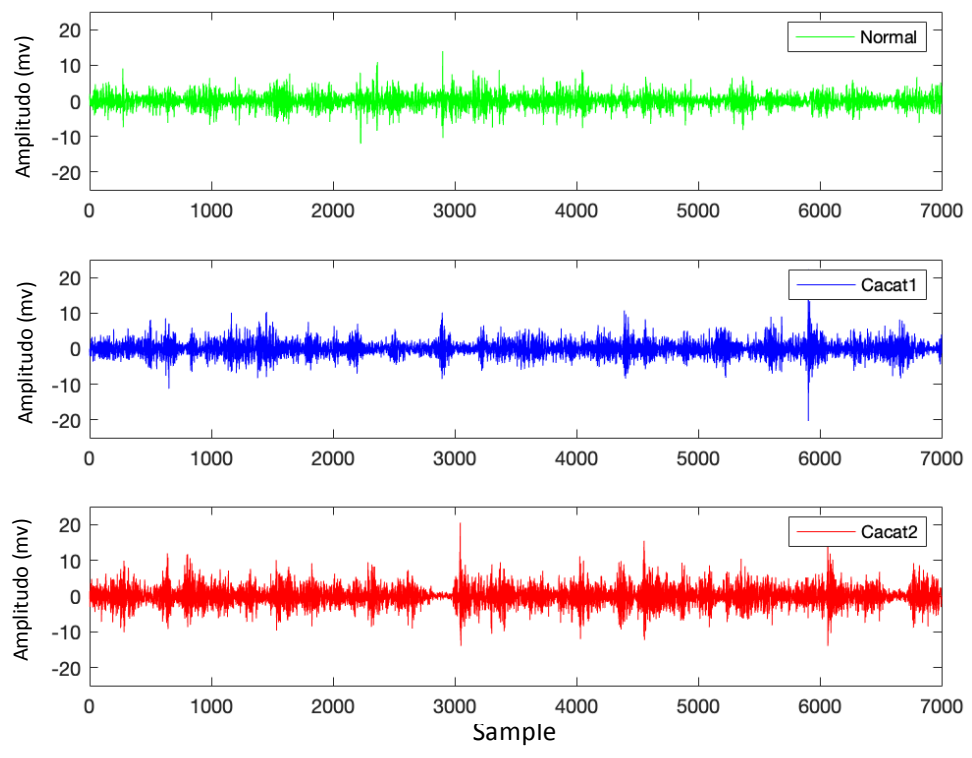

Gambar 7. Plot domain waktu
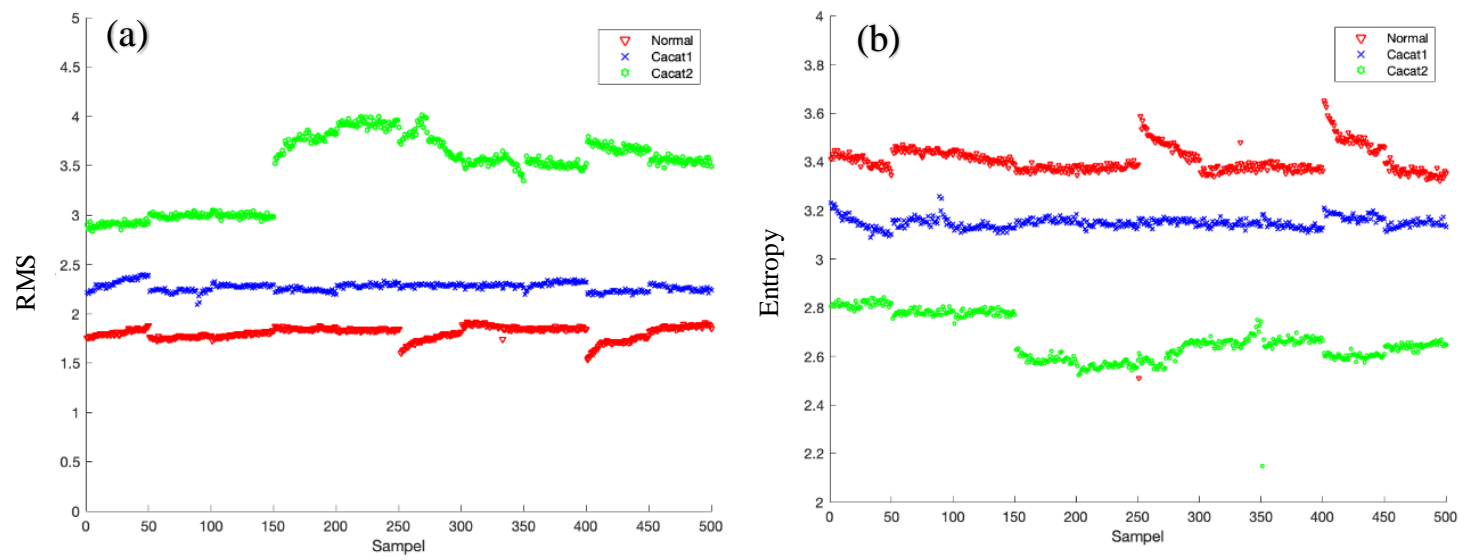

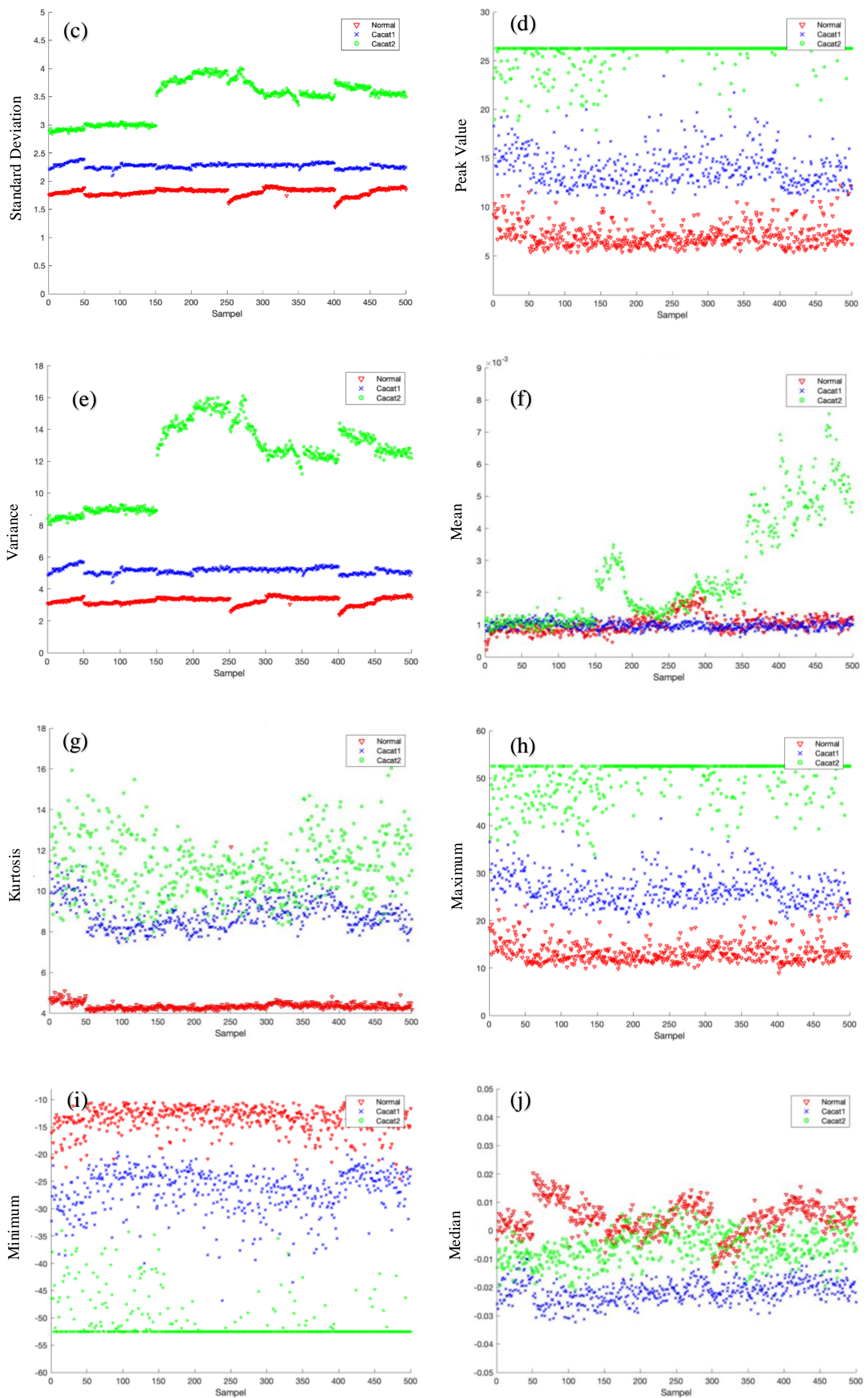

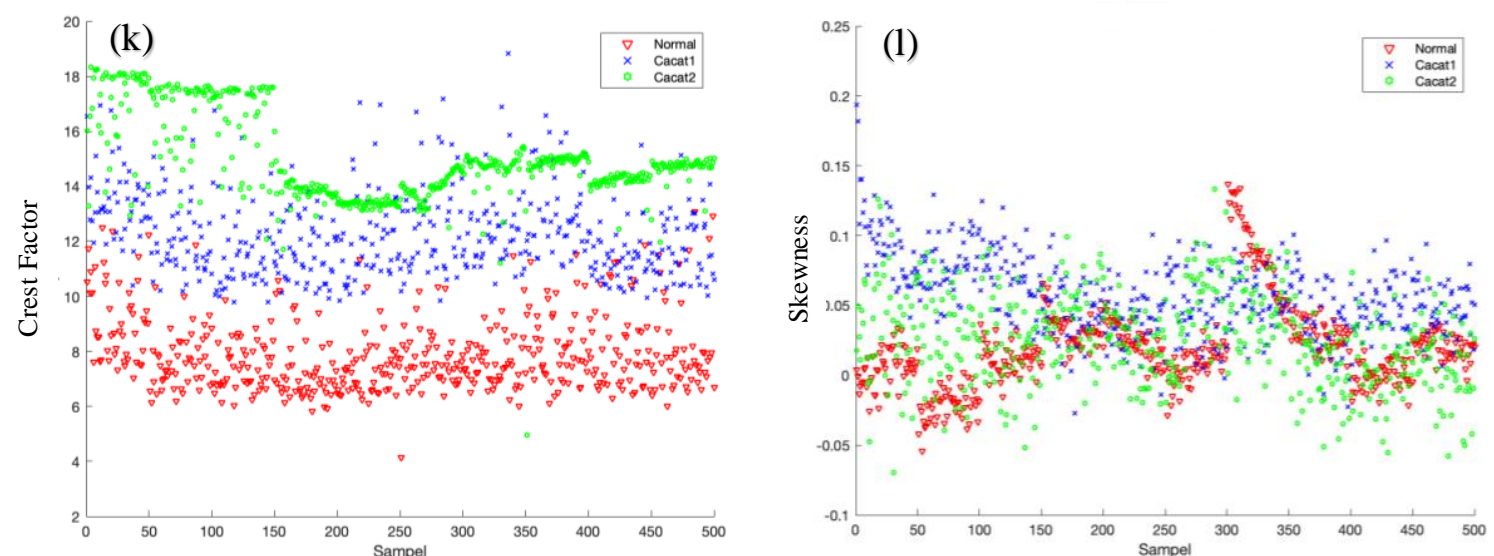

Gambar 8. Plot parameter statistik domain waktu, (a) Parameter RMS, (b) Parameter Entropy, (c) Parameter Standard Deviation, (d) Parameter Peak Value, (e) Parameter Variance, (f) Parameter Mean, (g) Parameter Kurtosis, (h) Parameter Maximum, (i) Parameter Minimum, (j) Parameter Median, (k) Parameter Crest Factor, (1) Parameter Skewness

Seleksi parameter juga dilakukan menggunakan algoritma Relief Feature Selection dimana nilai yang diperoleh menentukan bobot pentingnya sebuah parameter relatif terhadap parameter lainnya. Gambar 9 menunjukkan parameter statistik diurutkan berdasarkan bobotnya. Terlihat bahwa enam parameter yaitu peak value, minimum, maximum, kurtosis, entropy dan crest factor mempunyai bobot lebih tinggi dibandingkan yang lainnya. Hasil yang diperoleh menggunakan teknik ini secara umum konsisten dengan hasil yang didapatkan pada Gambar 8. Parameter dengan bobot tinggi, seperti dapat dilihat pada Gambar 8, secara visual memisahkan kelas dengan sangat baik sedangkan parameter dengan bobot rendah gagal memisahkan kelas dan cenderung bercampur.

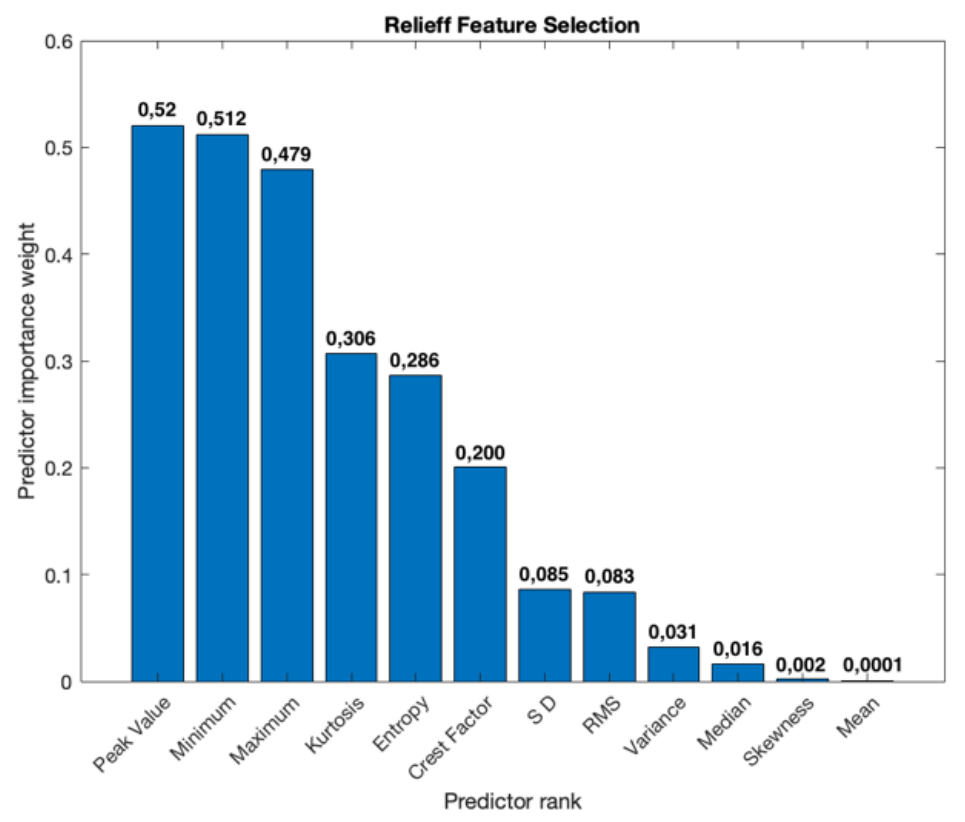

Gambar 9. Grafik peringkat parameter statistik

Dari hasil seleksi parameter statistik dipilih parameter statistik peak value dan kurtosis sebagai parameter input classifier karena mempunyai bobot tinggi dan secara visual pada Gambar 8 menujukkan pemisahan tiga kondisi roda gigi dengan baik. Secara khusus kurtosis dipilih karena mempunyai sensitifitas yang baik dalam mendeteksi data atau sinyal yang didominasi oleh impak sperti yang terjadi pada roda gigi. Proses training dan testing dilakukan dengan klasifikasi biner one vs one, yaitu menemukan hyperplane antara kondisi roda gigi normal vs cacat 1 dan kondisi roda gigi normal vs cacat 2 yang hasilnya dapat dilihat pada Gambar 10 dan Gambar 11. Hasil klasifikasi pada pada Gambar 10 memberikan tingkat separasi kelas sangat 
jelas antara kondisi normal vs cacat 1. Hyperplane mempunyai margin yang besar dengan support vector dari dua kelas berjarak maksimum. Observasi tidak menunjukkan tumpang tindih data antara kedua kelas tersebut yang bermakna akurasinya $100 \%$.

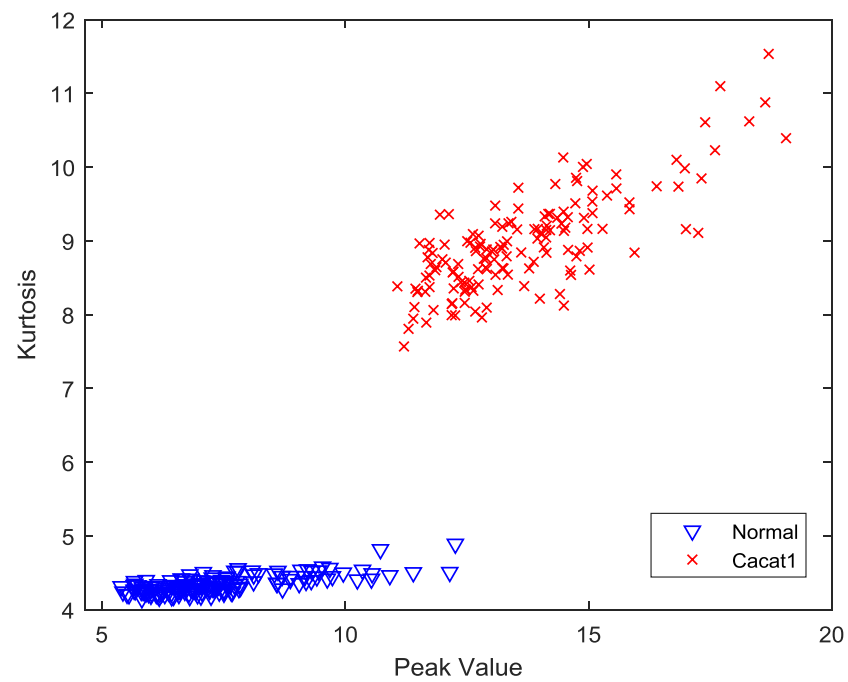

Gambar 10. Hasil klasifikasi kondisi roda gigi normal vs cacat 1

Hasil serupa ditunjukkan pada klasifikasi antara kondisi normal vs cacat 2 dimana proses testing menghasilkan hyperplane optimal dengan level pemisahan kelas yang maksimal. Akurasi didapatkan $100 \%$ karena tidak tampak kesalahan klasifikasi di kedua kelas tersebut. Parameter peak value dan kurtosis berhasil memisahkan kelas secara efektif, hal ini konsisten dengan seleksi visual dimana kurtosis berhasil memisahkan 3 kelas dengan jelas sedangkan hasil seleksi dengan algoritma feature relief menghasilkan bobot paling tinggi untuk peak value.

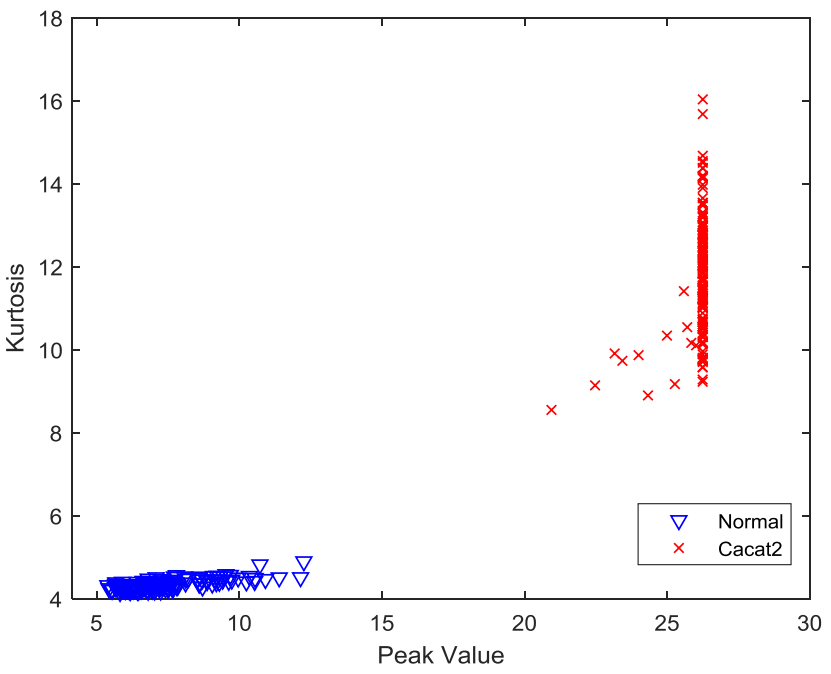

Gambar 11. Hasil klasifikasi kondisi roda gigi normal vs cacat 2

Klasifikasi multi-kelas one vs all menghasilkan akurasi $100 \%$ yang didapat dengan menghitung confusion matrix seperti ditunjukkan pada Gambar 12. Matriks tersebut memberikan informasi kesesuaian antara output dan target untuk ketiga kelas. Confusion matrix memberikan hasil $100 \%$ kesesuaian antara output dan target yang bermakna tidak terjadi salah klasifikasi untuk ketiga kelas tersebut. Hasil ini sekaligus mengkonfirmasi hasil one vs one dimana separasi biner dua kelas sangat jelas tanpa tumpang tindih data. Klasifikasi menggunakan data testing menghasilkan separasi yang jelas untuk ketiga kelas. Hyperplane memberikan margin yang sangat besar sehingga tidak terjadi kesalahan klasifikasi. 


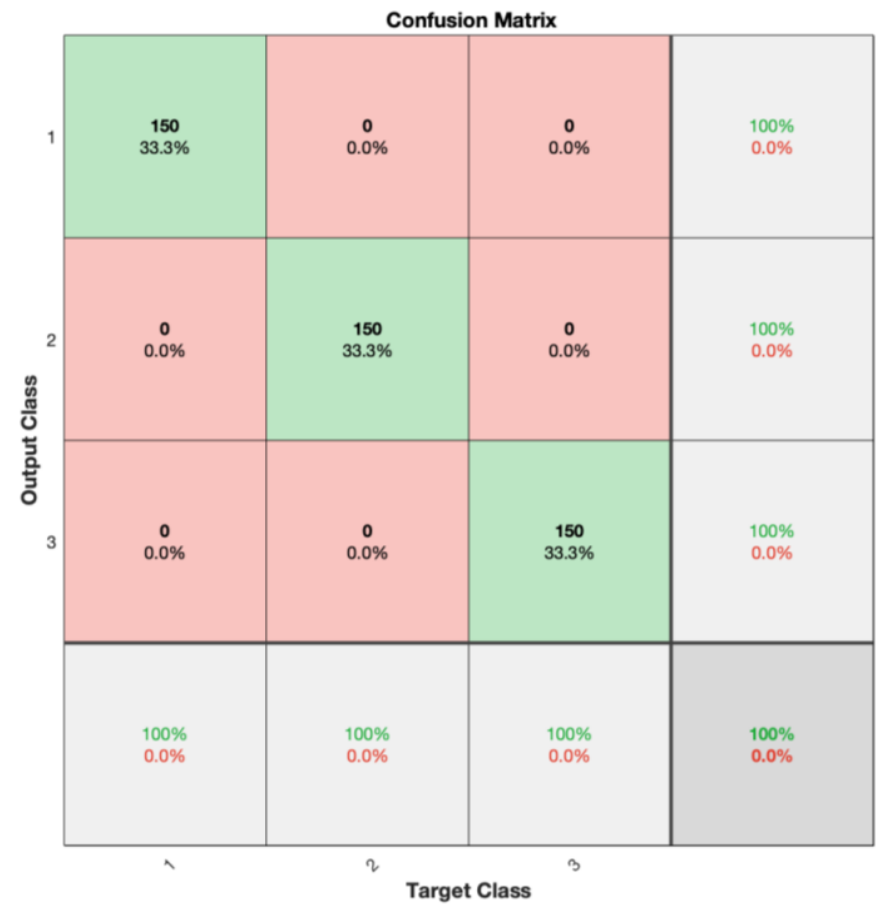

Gambar 12. Confusion matrix multi-kelas

\section{KESIMPULAN}

SVM berbasis sinyal vibrasi berhasil mendeteksi cacat roda gigi pada transmisi fan industri. Klasifikasi one vs one dan one vs all memberikan akurasi $100 \%$ dimana tidak terjadi kesalahan klasifikasi untuk ketiga kelas. Seleksi parameter statistik berdasarkan kombinasi seleksi visual dan algoritma relieffeature menghasilkan dua parameter terbaik yaitu peak value dan kurtosis untuk menjadi input SVM.

\section{DAFTAR PUSTAKA}

[1] SRINIVASAN, K. M., Fans and Blowers, 1 ed., New Delhi, New Age International Publisher, 2019.

[2] BLEIER, F. P., Fan Handbook, Selection, Application and Design, 1 ed., New York, McGraw-Hill Education, 1997.

[3] KAMIEL, B., N. PRASTOMO, and B. RIYANTA, "Ekstrasi Parameter Statistik Domain Waktu Dan Domain Frekuensi Untuk Mendeteksi Kavitasi Pada Pompa Sentrifugal Berbasis Principal Component Analysis (Pca)," Jurnal Rekayasa Mesin, v. 10, n. 2, pp. 165-177, 2019.

[4] SAHOO, S., R. A. LASKAR, J. K. DAS, and S. H. LASKAR, "Gear Fault Diagnosis and Classification Using Machine Learning Classifier," in Proceedings of the 2019 3rd International Conference on Intelligent Systems, Metaheuristics \& Swarm Intelligence, pp. 69-72,Male, Maldives, 2019.

[5] VERNEKAR, K., "Engine Gearbox Fault Diagnosis Using Machine Learning Approach," Journal of Quality in Maintenance Engineering, v. 24, n. 3, pp. 345-357, 2018.

[6] SAIMURUGAN, M., K. I. RAMACHANDRAN, V. SUGUMARAN, and N. R. SAKTHIVEL, "Multi Component Fault Diagnosis of Rotational Mechanical System Based on Decision Tree and Support Vector Machine," Expert Systems with Applications, v. 38, n. 4, pp. 3819-3826, 2011.

[7] KRISHNAKUMARI, A., A. ELAYAPERUMAL, M. SARAVANAN, and C. ARVINDAN, "Fault Diagnostics of Spur Gear Using Decision Tree and Fuzzy Classifier," The International Journal of Advanced Manufacturing Technology, v. 89, n. 9, pp. 3487-3494, 2017.

[8] SHAUL HAMEED, S., M. VAITHIYANATHAN, and M. KESAVAN, "Fault Detection in Single Stage Helical Planetary Gearbox Using Artificial Neural Networks (Ann) and Decision Tree with Histogram Features," 2019.

[9] MA, S., G. LIU, and Y. XU, "Gear Fault Diagnosis Based on Svm," in 2010 International Conference on Wavelet Analysis and Pattern Recognition, pp. 140-143, 2010.

[10] CHENG, J., D. YU, and Y. YANG, "A Fault Diagnosis Approach for Gears Based on Imf Ar Model and Svm," EURASIP Journal on Advances in Signal Processing, v. 2008, n. 1, p. 647135, 2008. 
[11] TANG, B., T. SONG, F. LI, and L. DENG, "Fault Diagnosis for a Wind Turbine Transmission System Based on Manifold Learning and Shannon Wavelet Support Vector Machine," Renewable Energy, v. 62, pp. 1-9, 2014.

[12] CHAO, L., C. LU, and J. MA, "An Approach to Fault Diagnosis for Gearbox Based on Reconstructed Energy and Support Vector Machine," Journal of Vibroengineering, v. 14, pp. 135-140, 2017.

[13] AMARNATH, M., V. SUGUMARAN, and H. KUMAR, "Exploiting Sound Signals for Fault Diagnosis of Bearings Using Decision Tree," Measurement, v. 46, n. 3, pp. 1250-1256, 2013.

[14] SUGUMARAN, V. and K. I. RAMACHANDRAN, "Effect of Number of Features on Classification of Roller Bearing Faults Using Svm and Psvm," Expert Systems with Applications, v. 38, n. 4, pp. 40884096, 2011.

[15] SHARMA, A., V. SUGUMARAN, and S. BABU DEVASENAPATI, "Misfire Detection in an Ic Engine Using Vibration Signal and Decision Tree Algorithms," Measurement, v. 50, pp. 370-380, 2014.

[16] VAPNIK, V. N., The Nature of Statistical Learning Theory, 2 ed., New York, Springer Science, 2000.

[17] VAPNIK, V. N., "An Overview of Statistical Learning Theory," IEEE Transactions on Neural Networks, v. 10, n. 5, pp. 988-999, 1999. 